\title{
Herbicide Conversion of a Sand Shinnery Oak (Quercus havardii) Community: Effects on Nitrogen
}

W.E. SEARS, C.M. BRITTON, D.B. WESTER, AND R.D. PETTIT

\section{Abstract}

Seasonal nitrogen dynamics were documented in an undisturbed sand shinnery oak (Quercus havardit) community and in similar areas treated with tebuthiuron 3 years and 6 years prior to sampling in 1981. Percent nitrogen was determined for above- and below-ground biomass compartments and for the soil by depth using semimicro Kjeldahl analyses. Total nitrogen by weight in the ecosystem showed no change from the untreated rangeland to the 3-year-old treatment but was $14 \%$ higher on the 6-year-old treatment than on the control. Less nitrogen oceurred in oak biomass compartments on the treated plots than on the control and more nitrogen occurred in the herbaceous compartments on the treated plots than on the control. Nitrogen (\%) was similar for all compartments on the untreated and 3-year treatments but was slightly higher for all compartments on the 6-year-old treatment than on the other 2 sites. Soil nitrogen was slightly higher $(3 \%)$ on the 3-year-old treatment than on the control and was $16 \%$ greater on the 6-year-old treatment than on the untreated rangeland.

\footnotetext{
Authors are research assistant, associate professor, research scientist, and associate professor, Department of Range and Wildlife Management, Texas Tech University, Lubbock 79409. This is a contribution of the College of Agricultural Sciences, Texas Tech University, Publication Number T-9-384.

This research was partially funded by Elanco Products Division of Eli Lilly and Company.

Manuscript accepted 26 December 1985.
}

JOURNAL OF RANGE MANAGEMENT 39(5), September 1986
Deep sandyland range sites dominated by sand shinnery oak (Quercus havardii) encompass about 2.3 million hectares in Texas, New Mexico, and Oklahoma. These areas, which are used primarily for livestock grazing, have low herbaceous production and require careful management to prevent erosion damage. Application of the herbicide tebuthiuron ( $N$ - 5-(1,1-dimethylethyl)-1,3,-4thiadiazol-2-yl]- $N, N^{\prime}$ dimethylurea) can control the oak and herbaceous production increases dramatically (Pettit 1979).

Herbage responses following herbicide applications have been documented (Pettit 1979 and Jones 1982); however, little is known of the herbicidal effects on basic ecosystem functions such as nutrient cycling. Changes in nutrient cycles could affect ecosystem stability and a loss of nutrients may lead to a decrease in overall productivity. Gottschalk and Shure (1979) found that the use of phenoxy herbicides $(2,4,5-T)$ may alter decomposition rates and result in imbalances in nutrient cycles.

The availability of nitrogen is an important factor determining structure, productivity, and stability of grassland ecosystems. Nitrogen concentrations are important not only in plant biomass production, but also in controlling decomposition and in improving forage quality (Reuss and Innis 1977).

Since herbicidal-induced death of oak should alter nitrogen dynamics in the sand shinnery oak ecosystem, this study was designed to evaluate an untreated oak community contrasted to similar areas treated with tebuthiuron 3 years $(1978)$ and 6 years 
(1975) prior to sampling. One specific objective was to evaluate weights of above- and below-ground nitrogen on each of the 3 sites.

\section{Materials and Methods}

Research was conducted in 1981 on deep sandy soils in southcentral Cochran and north-central Yoakum counties, approximately $25 \mathrm{~km}$ north and $5 \mathrm{~km}$ east of Plains, Texas. The study areas are located in the southern Great Plains in a sand dune system originating in eastern New Mexico. The sites are characterized by rolling sand hills interspersed with large semistabilized dunes and blow-out areas.

Climate of the area is warm-temperate and continental with an average annual precipitation of $40 \mathrm{~cm}$ (Soil Survey Staff 1964). Rainfall for the 1980 and 1981 seasons was 33.4 and $55.6 \mathrm{~cm}$, respectively. Precipitation patterns are characterized by widely scattered intense thunderstorms in spring and late summer. Temperatures range from $44^{\circ} \mathrm{C}$ to $-25^{\circ} \mathrm{C}$ with a frost-free period of about $\mathbf{2 0 0}$ days.

The primary soil in the study areas is a Brownfield fine sand (fine, mixed, thermic Arenic Aridic Paleustalf) (Soil Survey Staff 1964). It is characterized by an A horizon of approximately $95 \%$ sand ranging from 40 to $70 \mathrm{~cm}$ deep overlying a sandy clay loam argillic B horizon. The water holding capacity of this soil is low, infiltration rates are rapid (up to $70 \mathrm{~cm} / \mathrm{hr}$ ), and percolation is rapid until the wetting front reaches the $B$ horizon.

Species composition of the study area was described by Pettit (1979) and Jones (1982). The plant community consists of tall- to mid-grass species and increaser short-grass species under a dense canopy of sand shinnery oak. Following treatment of the shinnery oak community with tebuthiuron, physiognomy was changed from oak shrubland to mixed-grass prairie. Major grass species were the same on all 3 sites; however, the number of forb species was higher on the 2 treated areas than on the control.

Three adjacent $15 \times 30$-m study areas were established (1) in an untreated sand shinnery oak grassland, (2) in a similar community treated with tebuthiuron at $0.6 \mathrm{~kg}$ a.i. / ha 3 years (1978) prior to sampling, and (3) 6 years (1975) prior to sampling. All sites support similar vegetative composition, occur on Brownfield soils and have been managed similarly (light grazing June to September). All study areas were fenced prior to sampling to exclude grazing during the study. A 30-point grid was established within each study area and 4 sample points were randomly selected per area for each of 3 sample dates. Sample dates were: April, growth initiation; July, peak standing crop; and December, dormancy. Samples were collected for above- and below-ground compartments.

Above-ground biomass was harvested at ground level in a $1-\mathrm{m}^{2}$ circular quadrat and separated by compartment. Above-ground compartments sampled were: live oak stems, dead oak stems, live oak leaves, live herbaceous shoots (grass and forb shoots combined), dead herbaceous shoots, and litter.

Soil in a $0.25-\mathrm{m}^{2}$ circular plot was excavated to depths of (1) 0 to $15 \mathrm{~cm}$, (2) 15 to $30 \mathrm{~cm}$, (3) $30 \mathrm{~cm}$ to the top of the $B_{2} t$ horizon, and (4) $15 \mathrm{~cm}$ into the $B_{2} t$ horizon. Depth effects were evaluated using weights adjusted to $15-\mathrm{cm}$ increments for the variable depth, $30 \mathrm{~cm}$ to the top of the argillic horizon, resulting in a $60-\mathrm{cm}$ soil profile sample for all 3 treatments. The soil in each depth increment was placed in separate burlap bags and transported to the laboratory for root separation. Soil from each depth layer was sieved to pass a double layer of $1.6-\mathrm{mm}$ mesh screen to recover the fine root fragments.

Below-ground biomass was separated into large oak roots $(>2$ $\mathrm{mm}$ ), small oak roots $(<2 \mathrm{~mm}$ ), and herbaceous roots (grass and forb roots combined). Below-ground litter found at depth 1 (0-15 $\mathrm{cm}$ ) was surface litter that had been buried by the shifting, blowing surface sand. Vegetative samples were dried at $60^{\circ} \mathrm{C}$ in a forced air oven to a constant weight and then weighed to the nearest $0.01 \mathrm{~g}$.

Prior to excavation of each soil layer for root recovery, soil samples were collected for nitrogen and organic matter analyses. Five subsamples were taken at each depth using a $2.5-\mathrm{cm}$ diameter soil probe. All samples were dried to a constant weight at $60^{\circ} \mathrm{C}$ in a forced air oven then weighed to the nearest $0.01 \mathrm{~g}$. Plant samples were ground in a Wiley mill to pass a $0.5-\mathrm{mm}$ ( 40 -mesh) screen and soil samples were ground by hand using a mortar and pestle.

Nitrogen determinations were made using the semimicro Kjeldahl method described by Bremner (1960). Soil organic matter was determined using the Walkley-Black method (U.S. Soil Conservation Service, 1972) for use in developing $\mathrm{C} / \mathrm{N}$ ratios for the soil and various vegetative compartments. The concentration of nitrogen as a percentage was multiplied by the biomass weight to arrive at the weight of nitrogen in the various compartments. Nitrogen by weight is used for all comparisons between treatments.

Total seasonal nitrogen weights were calculated by adding nitrogen across sampling dates for each treatment. Nitrogen for each compartment was analyzed in a completely randomized design with 3 replications and 4 samples per replication. Treatments were main plots and sampling dates were subplots in a repeated measures analysis. Primary interest focused on treatment comparison. When dates and treatments interacted, treatments were compared within each date (e.g., Steel and Torrie 1980:386) with Duncan's new multiple range test. Nitrogen concentration (\%) is presented with nitrogen weights for descriptive purposes. Below-ground nitrogen was analyzed as a completely randomized design in a splitplot arrangement. Each sampling date was analyzed separately; treatments were main plots and depths were subplots in the splitplot arrangement. Primary interest focused on treatment comparison. When depths and treatments interacted, treatments were compared within each depth with Duncan's new multiple range test.

\section{Results and Discussion}

Total nitrogen weight was similar on untreated and 3-year-old treated plots. The 6-year-old treatment showed a $14 \%$ increase over the untreated plot (Table 1). This difference indicated a trend but was not statistically significant. The increase was primarily a result of an increase in soil nitrogen on the 6-year-old treated plots. Soil nitrogen apparently increased as a result of increased soil organic matter from the decomposing oak biomass.

\section{Above-ground Biomass}

The percentage of the total nitrogen in the ecosystem that was found in above-ground biomass was about the same on all 3 sites. Above-ground nitrogen weight was $26 \%$ less on the 3-year-old treatment than on the untreated site and $30 \%$ less on the 6-year-old treatment than on the untreated site (Table 2). This decrease reflected a decrease in above-ground biomass due to the reductions in above-ground oak material and in litter on the 2 treated sites. The concentration of nitrogen, however, increased from the untreated to the 3-year-old and 6-year-old treatments.

Oak material contributed $26 \%$ of the above-ground nitrogen on the untreated rangeland but was not present on the 2 treated sites. Any above-ground oak material remaining on the treated plots was dead and was considered a part of the above-ground litter compartment.

Nitrogen weight and concentration in the above-ground herbaceous material increased from the untreated site to the 3-yearold and 6-year-old sites with the highest amounts on the 6-year-old treatment. The increase in the herbaceous nitrogen concentration may be a result of the abundance of forbs present on the treated sites and especially on the 6-year treatment. Forbs in the study area are higher in nitrogen than grasses (Biondini 1980); therefore, an increase in forb production would raise nitrogen concentration levels for above-ground herbaceous biomass. Biondini (1980) also found that nitrogen concentration in grasses increased following tebuthiuron treatment and remained higher than values for untreated grasses for at least 2 years. Nitrogen concentrations of 1.5 and $1.8 \%$ in the live herbaceous shoots on the 3-year-old and 6-year-old treatments, respectively, were higher than the $1.3 \%$ reported 1 year after treatment (Biondini 1980). This may indicate 
that changes due to treatment are longer-lived than originally expected. Concentrations in the untreated grasses in this study (1.2\%) were similar to those reported by Biondini $(1.1 \%)$.

Litter nitrogen weight decreased from the untreated to the 2 treated sites primarily as a result of a decrease in amounts of litter present on the 2 treated sites. The concentration of nitrogen in the litter was similar on all 3 sites.

\section{Below-ground Biomass}

Nitrogen weight in below-ground biomass (excluding soil organic matter) was approximately equal on the control and on the 3-yearold treatment but was $20 \%$ less on the control compared to the 6-year-old treatment (Table 3). Nitrogen concentration of the below-ground biomass was greater on treated than untreated plots. Nitrogen weight and concentration in below-ground litter showed very little change by treatment but was slightly lower on the treated sites.

Oak-root nitrogen (large and small roots combined) weight was
$10 \%$ lower on the 3-year-old treatment than on the untreated area and $30 \%$ lower on the 6-year-old treatment than on the untreated area (Table 3). Total oak-root nitrogen decreased with increasing soil depth, regardless of treatment (Table 4). Nitrogen concentration of oak roots increased with treatment age. Oak-root nitrogen concentration did not change with soil depth on the control but was highest at depths 1 and 4 on the 3-year-old and 6-year-old treatments. Changes in oak-root nitrogen concentration with soil depth on the 2 treated areas was probably due to differential rates of decomposition as affected by soil depth. There was no difference by depth on the untreated area because most of the oak root material was still alive.

Total oak root nitrogen concentration was greater on the tebuthiuron-treated rangeland compared to the untreated site. Nitrogen weight in the oak roots remained constant with death and decomposition, while carbon was lost as carbon dioxide during decomposition. This resulted in a narrowing of the $C / N$ ratio (Clark and Campion 1976). Small oak roots showed this trend of

Table 1. Seasonal nitrogen weights (kg/ha) for major compartments on control, 3-year old and 6-year old tebuthiuron treated sand shinnery oak rangeland in west Texas. (Nitrogen concentration $(\%)$ is listed in parentheses below nitrogen weight).

\begin{tabular}{|c|c|c|c|c|c|c|c|c|c|c|c|c|}
\hline \multirow[b]{3}{*}{ Compartment } & \multicolumn{12}{|c|}{ Treatment } \\
\hline & \multicolumn{3}{|c|}{ Control } & \multicolumn{3}{|c|}{ 3-Year } & \multicolumn{3}{|c|}{ 6-Year } & \multicolumn{3}{|c|}{ Average } \\
\hline & April & July & Dec. & April & July & Dec. & April & July & Dec. & Control & 3-Year & 6-Year \\
\hline Total oak & $\begin{array}{l}132 \\
(.57)\end{array}$ & $\begin{array}{c}133 \\
(.79)\end{array}$ & $\begin{array}{c}121 \\
(.64)\end{array}$ & $\begin{array}{c}111 \\
(.57)\end{array}$ & $\begin{array}{c}118 \\
(.60)\end{array}$ & $\begin{array}{r}88 \\
(.60)\end{array}$ & $\begin{array}{r}94 \\
(.64)\end{array}$ & $\begin{array}{c}81 \\
(.64)\end{array}$ & $\begin{array}{r}72 \\
(.63)\end{array}$ & $\begin{array}{c}129 \mathrm{~A}^{1} \\
(.60)\end{array}$ & $\begin{array}{l}106 \mathrm{~B} \\
(.59)\end{array}$ & $\begin{array}{c}82 C \\
(.64)\end{array}$ \\
\hline Total herbaceous & $\begin{array}{c}9 b^{2} \\
(.67)\end{array}$ & $\begin{array}{l}11 \mathrm{c} \\
(.80)\end{array}$ & $\begin{array}{l}11 \mathrm{c} \\
(.57)\end{array}$ & $\begin{array}{c}26 a \\
(.76)\end{array}$ & $\begin{array}{r}50 \mathrm{a} \\
(.75)\end{array}$ & $\begin{array}{r}44 a \\
(.57)\end{array}$ & $\begin{array}{r}28 \mathrm{a} \\
(.87)\end{array}$ & $\begin{array}{l}38 b \\
(.75)\end{array}$ & $\begin{array}{c}29 \mathrm{~b} \\
(.70)\end{array}$ & $\begin{array}{c}10 \\
(.68)\end{array}$ & $\begin{array}{c}40 \\
(.69)\end{array}$ & $\begin{array}{r}32 \\
(.77)\end{array}$ \\
\hline Total litter & $\begin{array}{c}74 \\
(.96)\end{array}$ & $\begin{array}{c}57 \\
(.93)\end{array}$ & $\begin{array}{r}72 \\
(.83)\end{array}$ & $\begin{array}{r}48 \\
(.95)\end{array}$ & $\begin{array}{r}60 \\
(.90)\end{array}$ & $\begin{array}{r}56 \\
(.79)\end{array}$ & $\begin{array}{r}49 \\
(.94)\end{array}$ & $\begin{array}{r}32 \\
(.87)\end{array}$ & $\begin{array}{r}61 \\
(.94)\end{array}$ & $\begin{array}{l}68 \mathrm{~A} \\
(.91)\end{array}$ & $\begin{array}{l}55 A \\
(.88)\end{array}$ & $\begin{array}{l}47 \mathrm{~A} \\
(.92)\end{array}$ \\
\hline Total soil & $\begin{array}{l}1346 \mathrm{~b} \\
(.014)\end{array}$ & $\begin{array}{l}2026 \mathrm{a} \\
(.021)\end{array}$ & $\begin{array}{l}1479 a \\
(.015)\end{array}$ & $\begin{array}{l}1611 b \\
(.016)\end{array}$ & $\begin{array}{l}1791 \mathrm{a} \\
(.018)\end{array}$ & $\begin{array}{l}1581 \mathrm{a} \\
(.016)\end{array}$ & $\begin{array}{l}2153 \mathrm{a} \\
(.022)\end{array}$ & $\begin{array}{l}1878 a \\
(.019)\end{array}$ & $\begin{array}{l}1737 a \\
(.017)\end{array}$ & $\begin{array}{l}1617 \\
(.017)\end{array}$ & $\begin{array}{l}1661 \\
(.017)\end{array}$ & $\begin{array}{l}1923 \\
(.019)\end{array}$ \\
\hline Total nitrogen & $1561 \mathrm{a}$ & $2227 a$ & $1682 a$ & $1796 \mathrm{a}$ & $2019 a$ & $1768 \mathrm{a}$ & 2323a & $2029 a$ & $1898 a$ & 1824 & 1861 & 2084 \\
\hline
\end{tabular}

1Treatment averages for each compartment followed by the same upper case letter are not significantly different $(P>0.05)$.

2Treatment means for each compartment within a sampling date followed by the same lower case letter are not significantly different $(P>0.05$ ).

Table 2. Seasonal nitrogen weights (kg/ha) for above-ground compartments on control, 3-year old and 6-year old tebuthiuron treated sand shinnery oak rangeland in west Texas. (Nitrogen concentration $(\%)$ is listed in parentheses below nitrogen weight).

\begin{tabular}{|c|c|c|c|c|c|c|c|c|c|c|c|c|}
\hline \multirow[b]{3}{*}{ Compartment } & \multicolumn{12}{|c|}{ Treatment } \\
\hline & \multicolumn{3}{|c|}{ Control } & \multicolumn{3}{|c|}{ 3-Year } & \multicolumn{3}{|c|}{ 6-Year } & \multicolumn{3}{|c|}{ Average } \\
\hline & April & July & Dec. & April & July & Dec. & April & July & Dec. & Control & 3-Year & 6-Year \\
\hline Live oak stems! & $\begin{array}{l}4.5 \\
(.62)\end{array}$ & $\begin{array}{c}3.7 \\
(.65)\end{array}$ & $\begin{array}{c}4.9 \\
(.62)\end{array}$ & 0 & 0 & 0 & 0 & 0 & 0 & $\begin{array}{l}4.4 \\
(.63)\end{array}$ & $\begin{array}{l}0 \\
(0)\end{array}$ & $\begin{array}{c}0 \\
(0)\end{array}$ \\
\hline Dead oak stems ${ }^{1}$ & $\begin{array}{c}3.0 \\
(.57)\end{array}$ & $\begin{array}{l}1.7 \\
(.60)\end{array}$ & $\begin{array}{l}0.0 \\
(0)\end{array}$ & $\mathbf{0}$ & 0 & 0 & 0 & 0 & 0 & $\begin{array}{l}1.6 \\
(.59)\end{array}$ & $\begin{array}{c}0 \\
(0)\end{array}$ & $\begin{array}{c}0 \\
(0)\end{array}$ \\
\hline Live oak leaves ${ }^{1}$ & $\begin{array}{l}0.0 \\
(0)\end{array}$ & $\begin{array}{l}16.1 \\
(1.42)\end{array}$ & $\begin{array}{c}0.0 \\
(0)\end{array}$ & $\mathbf{0}$ & 0 & $\mathbf{0}$ & 0 & 0 & $\mathbf{0}$ & $\begin{array}{c}5.4 \\
(1.42)\end{array}$ & $\begin{array}{c}0 \\
(0)\end{array}$ & $\begin{array}{c}0 \\
(0)\end{array}$ \\
\hline $\begin{array}{l}\text { Total above-ground } \\
\text { oak }\end{array}$ & $\begin{array}{l}7.5 \\
(.60)\end{array}$ & $\begin{array}{l}21.5 \\
(.89)\end{array}$ & $\begin{array}{r}4.9 \\
(.62)\end{array}$ & 0 & 0 & 0 & $\mathbf{0}$ & 0 & 0 & $\begin{array}{l}11.3 \\
(.70)\end{array}$ & $\begin{array}{l}0 \\
(0)\end{array}$ & $\begin{array}{l}0 \\
(0)\end{array}$ \\
\hline Live herbaceous shoots & $\begin{array}{c}0.4 \mathrm{a}^{2} \\
(1.67)\end{array}$ & $\begin{array}{r}2.0 \mathrm{~b} \\
(1.09)\end{array}$ & $\begin{array}{l}0.7 \mathrm{a} \\
(.93)\end{array}$ & $\begin{array}{r}0.4 a \\
(2.22)\end{array}$ & $\begin{array}{r}14.5 \mathrm{a} \\
(.94)\end{array}$ & $\begin{array}{r}0.5 \mathrm{a} \\
(1.43)\end{array}$ & $\begin{array}{c}1.1 \mathrm{a} \\
(2.82)\end{array}$ & $\begin{array}{l}16.9 \mathrm{a} \\
(.93)\end{array}$ & $\begin{array}{r}2.0 \mathrm{a} \\
(1.65)\end{array}$ & $\begin{array}{l}1.0 \\
(1.23)\end{array}$ & $\begin{array}{c}5.1 \\
(1.53)\end{array}$ & $\begin{array}{c}6.7 \\
(1.80)\end{array}$ \\
\hline Dead herbaceous shoots & $\begin{array}{l}1.6 \mathrm{~b} \\
(.66)\end{array}$ & $\begin{array}{l}0.2 \mathrm{a} \\
(.83)\end{array}$ & $\begin{array}{l}0.9 \mathrm{~b} \\
(.45)\end{array}$ & $\begin{array}{l}2.3 \mathrm{~b} \\
(.79)\end{array}$ & $\begin{array}{l}1.1 \mathrm{a} \\
(.52)\end{array}$ & $\begin{array}{r}11.8 \mathrm{a} \\
(.52)\end{array}$ & $\begin{array}{l}7.0 \mathrm{a} \\
(.99)\end{array}$ & $\begin{array}{l}3.3 \mathrm{a} \\
(.72)\end{array}$ & $\begin{array}{l}9.7 \mathrm{a} \\
(.68)\end{array}$ & $\begin{array}{l}0.9 \\
(.65)\end{array}$ & $\begin{array}{l}5.1 \\
(.61)\end{array}$ & $\begin{array}{l}6.7 \\
(.80)\end{array}$ \\
\hline $\begin{array}{l}\text { Total above-ground } \\
\text { herbaceous }\end{array}$ & $\begin{array}{r}2.0 \mathrm{~b} \\
(1.17)\end{array}$ & $\begin{array}{l}2.2 \mathrm{c} \\
(.96)\end{array}$ & $\begin{array}{l}1.7 \mathrm{~b} \\
(.69)\end{array}$ & $\begin{array}{r}2.7 \mathrm{~b} \\
(1.55)\end{array}$ & $\begin{array}{r}15.6 \mathrm{~b} \\
(.73)\end{array}$ & $\begin{array}{r}12.4 \mathrm{a} \\
(.98)\end{array}$ & $\begin{array}{r}8.1 a \\
(1.91)\end{array}$ & $\begin{array}{r}20.3 a \\
(.83)\end{array}$ & $\begin{array}{l}11.7 a \\
(1.17)\end{array}$ & $\begin{array}{l}2.0 \\
(.94)\end{array}$ & $\begin{array}{l}10.2 \\
(1.09)\end{array}$ & $\begin{array}{r}13.4 \\
(1.30)\end{array}$ \\
\hline Above-ground litter & $\begin{array}{l}41.9 \mathrm{a} \\
(1.03)\end{array}$ & $\begin{array}{l}19.8 \mathrm{a} \\
(.97)\end{array}$ & $\begin{array}{l}31.3 \mathrm{a} \\
(.96)\end{array}$ & $\begin{array}{r}25.4 \mathrm{~b} \\
(.95)\end{array}$ & $\begin{array}{r}22.2 \mathrm{a} \\
(.88)\end{array}$ & $\begin{array}{r}20.4 \mathrm{a} \\
(.86)\end{array}$ & $\begin{array}{r}16.5 \mathrm{~b} \\
(.95)\end{array}$ & $\begin{array}{r}15.1 \mathrm{a} \\
(.86)\end{array}$ & $\begin{array}{l}21.4 \mathrm{a} \\
(1.02)\end{array}$ & $\begin{array}{l}31.0 \\
(.99)\end{array}$ & $\begin{array}{c}22.7 \\
(.90)\end{array}$ & $\begin{array}{c}17.7 \\
(.94)\end{array}$ \\
\hline Total above-ground & $\begin{array}{l}51.4 \\
(.93)\end{array}$ & $\begin{array}{l}43.5 \\
(.94)\end{array}$ & $\begin{array}{l}37.8 \\
(.76)\end{array}$ & $\begin{array}{l}21.8 \\
(1.25)\end{array}$ & $\begin{array}{l}37.8 \\
(.81)\end{array}$ & $\begin{array}{l}32.8 \\
(.92)\end{array}$ & $\begin{array}{l}24.6 \\
(1.43)\end{array}$ & $\begin{array}{l}35.3 \\
(.85)\end{array}$ & $\begin{array}{l}33.1 \\
(1.10)\end{array}$ & $\begin{array}{c}44.2 \mathrm{~A}^{3} \\
(.88)\end{array}$ & $\begin{array}{r}32.9 A \\
(.99)\end{array}$ & $\begin{array}{l}31 \mathrm{~A} \\
(1.13)\end{array}$ \\
\hline
\end{tabular}

IBiomass in these compartments was not present in 3-year old and 6-year old treatments.

2Treatment means for each compartment within a sampling date followed by the same lower case letter are not significantly different $(P>0.05$ ).

${ }^{3}$ Treatment averages for each compartment followed by the upper case letter are not significantly different $(P>0.05)$. 
increasing nitrogen concentration following treatment; however, the large oak roots did not, which may reflect the slow rate of decomposition in these larger roots.

Herbaceous root nitrogen weight was 3.5-fold greater on the 3-year-old treatment than on the untreated site and 2-fold greater on the 6-year-old treatment than on the untreated site (Table 3). The nitrogen concentration increased with treatment age from the untreated site. Herbaceous root nitrogen weight was highest in the surface $15 \mathrm{~cm}$ regardless of treatment. Nitrogen concentration, however, decreased with increasing soil depth on the untreated site but varied irregularly by soil depth on the 2 treated sites.

Approximately $98 \%$ of the total nitrogen in the oak ecosystem occurred in the soil and only $8 \%$ of the total was found in distinguishable root biomass. This relationship was not affected by treatment. This $\mathbf{9 0 \%}$ corresponds to the $92 \%$ reported for a shortgrass prairie site (Clark and Campion 1976). Soil nitrogen was similar on the untreated site and on the 3-year-old treatment. There was, however, a $16 \%$ increase from the untreated site to the 6-yeartreatment. The increase in soil nitrogen on the 6-year-old treatment may reflect an increase in soil organic matter that resulted from the increased decomposition of oak material on that site. The 2- and 3-fold increases in herbaceous root biomass on the 3-year-old and 6-year-old treatments, respectively, may also add additional organic matter and therefore nitrogen to the soils on the treated areas. Herbaceous roots are short-lived (Dahlman and Kucera 1965, Sims and Singh 1971, Bartos and Jameson 1974) and decompose rapidly (Weaver 1947, Kucera et al. 1967) thereby releasing large amounts of organic matter and consequently nitrogen into the soil.

The nitrogen concentration of the soil on all 3 sites was low and ranged from $0.017 \%$ on the untreated site to $0.019 \%$ on the 6-yearold treatment. Soil Survey Staff (1964) listed a range of 0.011 to $0.019 \%$ on Brownfield soils in an adjacent area. Soil nitrogen was highest in the surface $15 \mathrm{~cm}$ (depth 1) and in the upper $15 \mathrm{~cm}$ of the $B_{2}$ horizon (depth 4). Nitrogen movement through the sand by leaching may be deposited in the $B_{2}$ horizon. There was also a proliferation of fine herbaceous roots at and in this horizon which would add to the organic matter and consequently the nitrogen found at that depth. Nitrogen distribution in grassland soils tends to approximate the depth of grass root development (Weaver et al.

Table 3. Seasonal nitrogen weights ( $\mathrm{kg} / \mathrm{ha}$ ) for below-ground compartments on control, 3-year old and 6-year old tebuthluron treated sand shinnery oak rangeland in west Texas. (Nitrogen concentration $(\%)$ is listed in parentheses below nitrogen weight).

\begin{tabular}{|c|c|c|c|c|c|c|c|c|c|c|c|c|}
\hline \multirow[b]{3}{*}{ Compartment } & \multicolumn{12}{|c|}{ Treatment } \\
\hline & \multicolumn{3}{|c|}{ Control } & \multicolumn{3}{|c|}{ 3-Year } & \multicolumn{3}{|c|}{ 6-Year } & \multicolumn{3}{|c|}{ Average } \\
\hline & April & July & Dec. & April & July & Dec. & April & July & Dec. & Control & 3-Year & 6-Year \\
\hline Large oak roots & $\begin{array}{l}80.6 \\
(.50)\end{array}$ & $\begin{array}{l}68.9 \\
(.51)\end{array}$ & $\begin{array}{l}77.9 \\
(.53)\end{array}$ & $\begin{array}{l}80.3 \\
(.50)\end{array}$ & $\begin{array}{c}75.2 \\
(.51)\end{array}$ & $\begin{array}{c}51.6 \\
(.49)\end{array}$ & $\begin{array}{c}59.7 \\
(.53)\end{array}$ & $\begin{array}{r}43.1 \\
(.52)\end{array}$ & $\begin{array}{l}37.1 \\
(.52)\end{array}$ & $\begin{array}{l}75.8 A^{1} \\
(.51)\end{array}$ & $\begin{array}{l}69.0 \mathrm{~A} \\
(.50)\end{array}$ & $\begin{array}{l}46.6 \mathrm{~B} \\
(.52)\end{array}$ \\
\hline Small oak roots & $\begin{array}{l}44.0 \\
(.67)\end{array}$ & $\begin{array}{l}42.6 \\
(.75)\end{array}$ & $\begin{array}{l}38.0 \\
(.61)\end{array}$ & $\begin{array}{l}30.3 \\
(.77)\end{array}$ & $\begin{array}{l}42.7 \\
(.75)\end{array}$ & $\begin{array}{l}36.1 \\
(.65)\end{array}$ & $\begin{array}{r}33.9 \\
(.81)\end{array}$ & $\begin{array}{l}38.4 \\
(.83)\end{array}$ & $\begin{array}{l}34.8 \\
(.71)\end{array}$ & $\begin{array}{l}41.5 \mathrm{~A} \\
(.68)\end{array}$ & $\begin{array}{l}36.4 \mathrm{~B} \\
(.72)\end{array}$ & $\begin{array}{l}35.7 \mathrm{~B} \\
(.78)\end{array}$ \\
\hline Total oak roots & $\begin{array}{l}124.6 \\
(.54)\end{array}$ & $\begin{array}{l}111.5 \\
(.54)\end{array}$ & $\begin{array}{l}115.9 \\
(.57)\end{array}$ & $\begin{array}{l}110.6 \\
(.57)\end{array}$ & $\begin{array}{l}118.0 \\
(.60)\end{array}$ & $\begin{array}{l}87.7 \\
(.60)\end{array}$ & $\begin{array}{l}93.6 \\
(.64)\end{array}$ & $\begin{array}{l}81.5 \\
(.64)\end{array}$ & $\begin{array}{l}71.8 \\
(.63)\end{array}$ & $\begin{array}{l}117.3 \mathrm{~A} \\
(.55)\end{array}$ & $\begin{array}{l}105.4 \mathrm{~A} \\
(.59)\end{array}$ & $\begin{array}{l}82.3 \mathrm{~B} \\
(.64)\end{array}$ \\
\hline Herbaceous roots & $\begin{array}{r}7.2 \\
(.57)\end{array}$ & $\begin{array}{r}8.8 \\
(.53)\end{array}$ & $\begin{array}{r}8.9 \\
(.53)\end{array}$ & $\begin{array}{l}23.0 \\
(.64)\end{array}$ & $\begin{array}{c}34.2 \\
(.59)\end{array}$ & $\begin{array}{l}31.4 \\
(.59)\end{array}$ & $\begin{array}{l}19.9 \\
(.64)\end{array}$ & $\begin{array}{l}17.5 \\
(.63)\end{array}$ & $\begin{array}{l}17.0 \\
(.64)\end{array}$ & $\begin{array}{l}8.3 \mathrm{C} \\
(.54)\end{array}$ & $\begin{array}{l}29.5 \mathrm{~A} \\
(.61)\end{array}$ & $\begin{array}{l}18.1 \mathrm{~B} \\
(.64)\end{array}$ \\
\hline Below-ground litter & $\begin{array}{l}32.0 \\
(.89)\end{array}$ & $\begin{array}{r}37.3 \\
(.88)\end{array}$ & $\begin{array}{l}40.3 \\
(.70)\end{array}$ & $\begin{array}{l}23.0 \\
(.95)\end{array}$ & $\begin{array}{l}37.9 \\
(.91)\end{array}$ & $\begin{array}{l}35.5 \\
(.71)\end{array}$ & $\begin{array}{l}32.2 \\
(.92)\end{array}$ & $\begin{array}{l}17.0 \\
(.88)\end{array}$ & $\begin{array}{l}39.8 \\
(.86)\end{array}$ & $\begin{array}{l}36.5 \mathrm{~A} \\
(.82)\end{array}$ & $\begin{array}{l}32.1 \mathrm{~A} \\
(.86)\end{array}$ & $\begin{array}{l}29.7 \mathrm{~A} \\
(.89)\end{array}$ \\
\hline $\begin{array}{l}\text { Total below-ground } \\
\text { biomass nitrogen }\end{array}$ & $\begin{array}{l}163.8 \\
(.67)\end{array}$ & $\begin{array}{l}157.7 \\
(.65)\end{array}$ & $\begin{array}{l}165.1 \\
(.60)\end{array}$ & $\begin{array}{l}156.6 \\
(.72)\end{array}$ & $\begin{array}{l}190.0 \\
(.70)\end{array}$ & $\begin{array}{l}154.6 \\
(.63)\end{array}$ & $\begin{array}{l}145.7 \\
(.73)\end{array}$ & $\begin{array}{l}116.0 \\
(.72)\end{array}$ & $\begin{array}{l}128.6 \\
(.71)\end{array}$ & $\begin{array}{l}162.2 \mathrm{~A} \\
(.59)\end{array}$ & $\begin{array}{l}167.1 \mathrm{~A} \\
(.63)\end{array}$ & $\begin{array}{l}130.1 \mathrm{~B} \\
(.67)\end{array}$ \\
\hline
\end{tabular}

ITreatment averages for each compartment followed by the same letter are not significantly different $(P>0.05)$.

Table 4. Below-ground nitrogen weights (kg/ha) for major components at four soil depths on control, 3-year old and 6-year old tebuthiuron treated sand shinnery oak rangeland in west Texas.

\begin{tabular}{|c|c|c|c|c|c|c|c|c|c|c|}
\hline \multirow[b]{2}{*}{ Compartment } & \multirow[b]{2}{*}{ Depth } & \multicolumn{3}{|c|}{ April } & \multicolumn{3}{|c|}{ July } & \multicolumn{3}{|c|}{ December } \\
\hline & & Control & 3-Year & 6-Year & Control & 3-Year & 6-Year & Control & 3-Year & 6-Year \\
\hline Large oak roots & $\begin{array}{c}1 \\
2 \\
3 \\
4 \\
\text { Avg }\end{array}$ & $\begin{array}{c}40 \mathrm{a}^{l} \\
24 \mathrm{~b} \\
8 \mathrm{a} \\
8 \mathrm{a} \\
20\end{array}$ & $\begin{array}{r}26 b \\
37 a \\
9 a \\
9 a \\
20\end{array}$ & $\begin{array}{c}27 b \\
15 b \\
7 a \\
12 a \\
15\end{array}$ & $\begin{array}{c}36 a \\
19 a b \\
8 a \\
6 a \\
17\end{array}$ & $\begin{array}{c}35 a \\
24 a \\
8 a \\
8 a \\
19\end{array}$ & $\begin{array}{r}15 b \\
13 b \\
7 a \\
8 a \\
11\end{array}$ & $\begin{array}{c}42 \\
17 \\
11 \\
8 \\
20 \mathrm{~A}\end{array}$ & $\begin{array}{c}17 \\
18 \\
8 \\
9 \\
13 \mathrm{~B}\end{array}$ & $\begin{array}{c}14 \\
11 \\
6 \\
6 \\
9 B\end{array}$ \\
\hline Small oak roots & $\begin{array}{c}1 \\
2 \\
3 \\
4 \\
\text { Avg }\end{array}$ & $\begin{array}{c}18 \\
11 \\
7 \\
8 \\
11 \mathrm{~A}\end{array}$ & $\begin{array}{c}14 \\
9 \\
4 \\
4 \\
8 B\end{array}$ & $\begin{array}{c}20 \\
8 \\
3 \\
3 \\
9 B\end{array}$ & $\begin{array}{c}22 \\
10 \\
6 \\
6 \\
11 \mathrm{~A}\end{array}$ & $\begin{array}{r}26 \\
10 \\
4 \\
4 \\
11 \mathrm{~A}\end{array}$ & $\begin{array}{r}21 \\
7 \\
4 \\
6 \\
10 A\end{array}$ & $\begin{array}{c}16 \\
12 \\
6 \\
5 \\
10 A\end{array}$ & $\begin{array}{r}16 \\
12 \\
5 \\
3 \\
9 A\end{array}$ & $\begin{array}{c}19 \\
8 \\
5 \\
4 \\
9 A\end{array}$ \\
\hline Herbaceous roots & $\begin{array}{c}1 \\
2 \\
3 \\
4 \\
\text { Avg }\end{array}$ & $\begin{array}{l}4.3 \mathrm{~b} \\
1.2 \mathrm{a} \\
0.7 \mathrm{a} \\
0.9 \mathrm{a} \\
1.8\end{array}$ & $\begin{array}{c}16.5 \mathrm{a} \\
2.6 \mathrm{a} \\
1.2 \mathrm{a} \\
2.8 \mathrm{a} \\
5.8\end{array}$ & $\begin{array}{c}18.1 \mathrm{a} \\
1.0 \mathrm{a} \\
0.3 \mathrm{a} \\
0.5 \mathrm{a} \\
5.0\end{array}$ & $\begin{array}{l}6.1 \mathrm{c} \\
1.1 \mathrm{~b} \\
0.6 \mathrm{a} \\
1.1 \mathrm{a} \\
2.2\end{array}$ & $\begin{array}{c}25.0 \mathrm{a} \\
5.3 \mathrm{a} \\
1.4 \mathrm{a} \\
2.6 \mathrm{a} \\
8.6\end{array}$ & $\begin{array}{c}14.1 \mathrm{~b} \\
1.5 \mathrm{~b} \\
0.8 \mathrm{a} \\
1.1 \mathrm{a} \\
4.4\end{array}$ & $\begin{array}{l}5.0 \mathrm{c} \\
0.9 \mathrm{a} \\
1.2 \mathrm{a} \\
1.9 \mathrm{a} \\
2.3\end{array}$ & $\begin{array}{c}22.8 \mathrm{a} \\
4.6 \mathrm{a} \\
19 . \mathrm{a} \\
2.1 \mathrm{a} \\
7.9\end{array}$ & $\begin{array}{c}13.9 \mathrm{~b} \\
1.4 \mathrm{a} \\
0.7 \mathrm{a} \\
1.0 \mathrm{a} \\
4.3\end{array}$ \\
\hline Soil & $\begin{array}{c}1 \\
2 \\
3 \\
4 \\
\text { Avg }\end{array}$ & $\begin{array}{l}533 \\
186 \\
170 \\
457 \\
337 B\end{array}$ & $\begin{array}{l}470 \\
316 \\
221 \\
604 \\
403 B\end{array}$ & $\begin{array}{l}689 \\
409 \\
247 \\
808 \\
538 A\end{array}$ & $\begin{array}{l}664 \\
330 \\
275 \\
758 \\
507 A\end{array}$ & $\begin{array}{l}606 \\
205 \\
172 \\
808 \\
448 A\end{array}$ & $\begin{array}{l}695 \\
225 \\
213 \\
744 \\
469 \mathrm{~A}\end{array}$ & $\begin{array}{c}330 \mathrm{~b} \\
239 \mathrm{ab} \\
193 \mathrm{a} \\
717 \mathrm{a} \\
370\end{array}$ & $\begin{array}{c}472 a \\
205 b \\
196 a \\
708 \\
395\end{array}$ & $\begin{array}{l}506 a \\
344 a \\
245 a \\
643 a \\
435\end{array}$ \\
\hline
\end{tabular}

Treatment means within a depth for each compartment and each sampling date followed by the same lower case letter are not significantly different $(P>0.05)$.

${ }_{2}^{2}$ Treatment averages for each compartment and each sampling date followed by the same upper case letter are not significantly different $(P>0.05)$. 


\section{5, Porter 1969).}

The soil-nitrogen system is so dynamic that any alteration in the environment shifts the system toward a new steady state condition (Porter 1969). By comparing nitrogen values from the untreated and treated sites to previous work in forest and grassland ecosystems, it can be seen that the sand shinnery oak-dominated ecosystem has nitrogen dynamics similar to a forest with long-lived woody material which decomposes slowly. In contrast, treated areas appear to be gradually developing nitrogen dynamics characteristics of a grassland ecosystem.

Nitrogen dynamics in the sand shinnery oak ecosystem have been altered by application of tebuthiuron. Differences were subtle at 3 years following oak control; however, after 6 years, certain patterns of change were well established. As a result of oak and litter decomposition, soil organic matter and consequently nitrogen by weight in the soil increased on the treated plots.

Roden and Bazilevich (1965) reported the nitrogen concentration of total biomass for various ecosystems as being $1.5 \%$ for desert, $1.2 \%$ for grassland, and $\mathbf{0 . 6 \%}$ for forest. Nitrogen concentrations of $0.6,0.7$, and $0.7 \%$ on the untreated site, 3-year-oldtreatment, and 6-year old treatment, respectively, indicated a similarity of all 3 sites to nitrogen values for forest ecosystems. This shows the importance of sand shinnery oak in influencing the nitrogen dynamics in the oak-grassland ecosystem, even on the tebuthiuron treated plots. In time the nitrogen concentrations on the treated areas may increase to the values representative for grasslands as indicated by the 1.1 and $1.3 \%$ concentrations of nitrogen in the herbaceous matter on the 3-year-old and 6-year-old treatments, respectively.

\section{Summary and Conclusions}

Nitrogen dynamics in the sand shinnery oak ecosystem have been altered as a result of herbicidal treatment. Three years following oak death the differences are subtle; however, after 6 years certain patterns of change are well established. As a result of oak death and decomposition, the total amount of nitrogen by weight in plant biomass decreased. There were increases in nitrogen in herbaceous matter; however, these did not totally counterbalance the losses from the oak and litter compartments. The pattern of decrease will continue until all of the oak material has decomposed. In spite of the decrease in nitrogen by weight in biomass compartments following treatment, soil nitrogen has increased on the treated sites. The soil organic matter increased as a result of oak and litter decomposition and as a result of the breakdown of herbaceous roots which increased.

Nitrogen as a percentage (concentration) increased from the control to the 6-year treatment for all compartments sampled. Increases in nitrogen concentration in oak material were due to a narrowing of the $\mathrm{c} / \mathrm{n}$ ratio during decomposition while increases in herbaceous material were a result of an increase in forb species high in nitrogen on the treated sites.

Porter (1979) stated that the soil-nitrogen system is so dynamic that any alteration in the environment shifts the system toward a new steady state condition. Such is the case in the sand shinnery oak ecosystem. By comparing nitrogen values from the control and treated sites to previous work done in forest and grassland ecosys- tems, it can be seen that the oak-dominated ecosystem has nitrogen dynamics similar to a forest with long-lived woody material slow to break down while the treated areas are moving toward the nitrogen dynamics of a grassland ecosystem.

There appear to be no drastic changes in nitrogen dynamics which could threaten future productivity on these sites. With proper grazing management to avoid overgrazing and damage to the ecosystem, the herbicide-converted grassland communities can maintain current production levels even as the oak biomass decomposes. Future fluctuations in production will occur primarily as a result of fluctuations in precipitation.

\section{Literature Cited}

Bartos, D.L., and D.A. Jameson. 1974. A dynamic root model. Amer. Mid. Natur. 91:499-504.

Blondini, M.E. 1980. Nutritive value of sandyland forages treated with different rates of tebuthiuron. M.S. Thesis, Texas Tech Univ., Lubbock, Texas.

Bremner, J.M. 1960. Determination of nitrogen in soil by the Kjeldahl method. J. Agr. Sci. 55:11-33.

Buckman, H.O., and N.C. Brady. 1960. The nature and properties of soils. The Macmillan Company, New York.

Clark, F.E., and M. Campion. 1976. Distribution of nitrogen in root materials of blue grama. J. Range Manage. 29:256-258.

Dahlman, R.C., and C.L. Kucera. 1965. Root productivity and turnover in native prairie. Ecology 46:84-89.

Gottechalk, M.R., and D.J. Shure. 1979. Herbicide effects on leaf litter decomposition processes in an oak-hickory forest. Ecology 60:143-151.

Jones, V.E. 1982. Effects of tebuthiuron on a sandy shinnery oak (Quercus havardii) community. Ph.D. Diss. Texas Tech Univ., Lubbock, Texas.

Kucera, C.L., R.C. Dahlman, and M.L. Koelling. 1967. Root productivity and turnover on an energy basis for tallgrass prairie. Ecology 48:536-541.

Pettit, R.D. 1979. Effects of picloram and tebuthiuron pellets on sand shinnery oak communities. J. Range Manage. 32:196-200.

Porter, L.K. 1969. Nitrogen in grassland ecosystems. p. 377-402. In: R.L. Dix and R.G. Beidleman (eds.). The Grassland Ecosystem: A Preliminary Synthesis. Proc. of the Information Synthesis Project, Grassland Biome, US/IBP Range Science Dep., Science Series 2, Colorado State Univ., Fort Collins.

Reuss, J.O., and G.S. Innis. 1977. A grassland flow simulation model. Ecology 58:379-388.

Rodin, L.E., and N.I. Bazilevich. 1965. Production and mineral cycling in terrestrial vegetation. (English translation by G.E. Fogg, 1967), Oliver and Boyd. Edinburgh.

Sims, P.L., and J.S. Singh. 1971. Herbage dynamics and net primary production in certain ungrazed and grazed grasslands in North America. p. 59-113. In: N.R. French (ed.). Preliminary Analysis of Structure and Function in Grasslands. Range Sciences Department Series 10. Colorado State Univ., Fort Collins.

Soil Conservation Service. 1972. Organic carbon. In: Soil Survey Laboratory Methods and Procedures for Collecting Soil Samples. Soil Survey Investigations Rep. No. 1. Soil Conserv. Serv., USDA.

Soil Survey Staff. 1964. Soil survey of Yoakum County, Texas. Soil Conserv. Serv. USDA Series 1960, No. 15.

Steel, R.G.D., and J.H. Torrie. 1980. Principles and procedures of statistics. McGraw-Hill Book Co., Inc., New York.

Weaver, J.E. 1947. Rate of deomposition of roots and rhizomes of certain range grasses in undisturbed prairie soil. Ecology 28:221-240.

Weaver, J.E., V.H. Houghon, and M.D. Weldon. 1935. Relation of root distribution to organic matter in prairie soil. Bot. Gaz. 96:389-420. 